\title{
Review of tenure refusal uncovers conflicts of interest
}

Rex Dalton, San Diego

The academic rights of an ecologist at the University of California, Berkeley, may have been violated when he was denied tenure last year, according to a report from the academic senate.

Ignacio Chapela was an outspoken critic of Berkeley's controversial academic-industrial partnership with the Swiss agribiotech firm Syngenta, which ended last year (see right). He was also the lead author of a disputed paper in Nature in which he asserted that genes from genetically modified crops had flowed into Mexican maize, and had become scattered throughout the genome (D. Quist and I. H. Chapela Nature 414, 541-543; 2001). After a

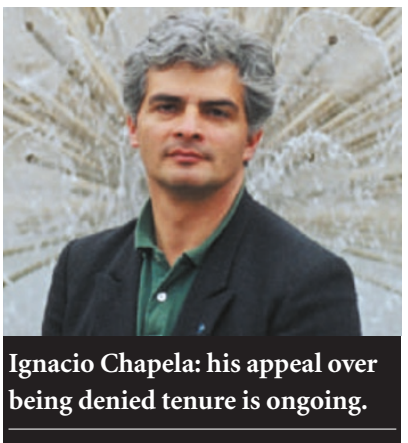
Rex Dalton, San Diego

Large-scale partnerships between industry and universities ought to be avoided completely, according to the author of an external report investigating such a deal at the University of California at Berkeley. Although the arrangement provided cash that energized research, the report says, it created conflicts of interest within the university.

The report was commissioned by the university's academic senate and conducted by Lawrence Busch, an agricultural sociologist at Michigan State University, East Lansing. It looks in detail at a controversial deal struck in 1998 between the university and a Swiss firm now known as Syngenta. The five-year agreement saw Syngenta contribute storm of criticism about the paper, Nature withdrew its support for the article, but the authors stand by their research.

Against this background, Chapela was denied tenure at Berkeley's College of Natural Resources in November 2003 (see Nature 426,$591 ; 2003)$. He appealed.

The resulting report, issued on 28 June, claims that Jasper Rine, a geneticist at the university who sat on a key committee reviewing Chapela's tenure, had conflicts of interest. It says that Rine had financial dealings with biotech firms, oversaw the Syngenta agreement and had cited Chapela's Nature paper as an example of poor science in one of his classes. Both the dean of Chapela's college and his department chair requested that Rine be taken from the committee four times; but Rine did not excuse himself nor did the committee chair ask him to leave. The report also says there was "unjustifiable" delay in the tenure-review process.

"I am glad the senate is able to rise to the occasion," says Chapela, whose contract has been extended while he appeals. Rine, Berkeley administrators and senate members would not comment on the report, citing its confidentiality. Such committee reports are rarely disclosed.

As the senate continues its inquiry, Chapela is hoping for a second tenure review. He has also filed two claims that may precede a lawsuit. In April, he accused the university of discrimination, saying that he was denied tenure because he is Hispanic. Early last month, he claimed he was victimized by the university for speaking out against the Syngenta deal. US $\$ 25$ million to facilities and the funding of faculty at the university's department of plant and microbial biology, in exchange for the right to capitalize on their discoveries. The deal ended last year; Syngenta officials say it was abandoned owing to a change in company strategy.

Following their two-year review, Busch and his eight colleagues conclude that the deal did not compromise academic research

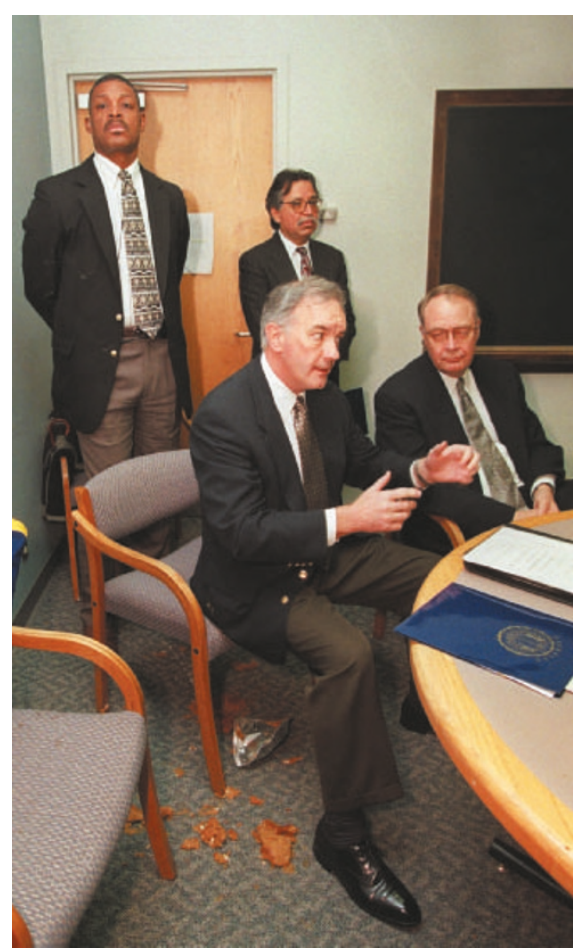

Tart reception: those announcing the privatepublic partnership were rebuffed with a pie. as many scientists had feared. But it did produce institutional conflicts of interest, Busch says, contributing to the denial of tenure to a faculty member who was critical of the deal (see left). It also failed to produce as many patent benefits as originally hoped.

Busch hopes the report will lead to a broader debate over academic-industrial relations at all US universities. "I think it is high time for serious discussions of what the devil we want our universities to be. Berkeley is a good place to start," says Busch. "I don't think you should hermetically insulate a university from the private sector. But this deal was a mistake." Most university-industry projects fund specific researchers or scientific groups rather than an entire academic unit, as the Berkeley pact did, notes Busch.

When the deal in question was initially announced (with Novartis, whose agriculture business became Syngenta), it was so loathed by students and scientists at the university that demonstrators threw a pie at the officials announcing it. There was a widespread perception that the Syngenta deal "compromised the mission of the university", says Busch. The academic senate pushed for and won university funding to conduct a $\$ 225,000$ analysis of the deal.

Commissioning an independent report on such an issue is an unusual move, says Sheldon Krimsky, a philosopher at Tufts University, Massachusetts, who studies academic institutions. If it were not for the academic senate's concerns, certain criticisms might never have come to light, he says. Berkeley's administrators conducted an internal review of the deal two years ago; they concluded that the Syngenta pact was a good deal.

The Busch report highlights how the money injected into the university did make a difference: 26 members of the faculty received financial support from Syngenta, with individual totals ranging from $\$ 60,000$ to $\$ 200,000$. And, during the five-year period, the department made 51 potentially patentable discoveries, 12 of which emerged from Syngenta-funded research. But, out of 20 patents produced, Syngenta is pursuing research on only six, and no licence agreements with the university have been negotiated for any of those.

The university's administrative leaders declined to be interviewed, but the provost Paul Gray issued a statement saying the report is under review. Collaborations are important to the university's mission, the statement says, but "the appropriateness and structure" of such agreements should be examined. Syngenta officials did not respond to Nature's request for an interview. 